\title{
Brain somatic mutations in SLC35A2 cause intractable epilepsy with aberrant $\mathrm{N}$-glycosylation
}

Nam Suk Sim, MD, Youngsuk Seo, MSc, Jae Seok Lim, DDS, PhD, Woo Kyeong Kim, BS, Hyeonju Son, BS, Heung Dong Kim, MD, PhD, Sangwoo Kim, PhD, Hyun Joo An, PhD, Hoon-Chul Kang, MD, PhD,*

Se Hoon Kim, MD, PhD, * Dong-Seok Kim, MD, PhD, * and Jeong Ho Lee, MD, PhD*

Neurol Genet 2018;4:e294. doi:10.1212/NXG.0000000000000294

\section{Abstract}

\section{Objective}

To identify whether somatic mutations in SLC35A2 alter N-glycan structures in human brain tissues and cause nonlesional focal epilepsy (NLFE) or mild malformation of cortical development (mMCD).

\section{Methods}

Deep whole exome and targeted sequencing analyses were conducted for matched brain and blood tissues from patients with intractable NLFE and patients with $\mathrm{mMCD}$ who are negative for mutations in mTOR pathway genes. Furthermore, tissue glyco-capture and nanoLC/mass spectrometry analysis were performed to examine $\mathrm{N}$-glycosylation in affected brain tissue.

\section{Results}

Six of the 31 (19.3\%) study patients exhibited brain-only mutations in SLC35A2 (mostly nonsense and splicing site mutations) encoding a uridine diphosphate (UDP)-galactose transporter. Glycome analysis revealed the presence of an aberrant N-glycan series, including high degrees of $\mathrm{N}$-acetylglucosamine, in brain tissues with SLC35A2 mutations.

\section{Conclusion}

Our study suggests that brain somatic mutations in SLC35A2 cause intractable focal epilepsy with NLFE or mMCD via aberrant N-glycosylation in the affected brain.
Correspondence

Dr. Lee

jhlee4246@kaist.ac.kr

*These authors contributed equally to this work.

From the Graduate School of Medical Science and Engineering (N.S.S., J.S.L., W.K.K., J.H.L.), KAIST; Asia Glycomics Reference Site (Y.S., H.J.A.); Graduate School of Analytical Science \& Technology (Y.S., H.J.A.), Chungnam National University, Daejeon, Korea; Department of Biomedical System informatics (H.S., S.K.), Brain Korea 21 PLUS Project for Medical Science, Yonsei University College of Medicine; Division of Pediatric Neurology (H.D.K., H.C.K.), Department of Pediatrics, Pediatric Epilepsy Clinics, Severance Children's Hospital; Epilepsy Research Institute (H.D.K., H.C.K.), Yonsei University College of Medicine; Department of Pathology (S.H.K.), Yonsei University College of Medicine, Seoul, Korea; and Pediatric Neurosurgery (D.S.K.), Severance Children's Hospital, Department of Neurosurgery, Yonsei University College of Medicine, Seoul, South Korea.

Funding information and disclosures are provided at the end of the article. Full disclosure form information provided by the authors is available with the full text of this article at Neurology.org/NG. 


\section{Glossary}

FCDII = focal cortical dysplasia type II; HexNAc = N-acetyl glucosamine; HME = hemimegalencephaly; $\mathbf{m M C D}=$ mild malformation of cortical development; NLFE = nonlesional focal epilepsy; VAF = variant allele frequency; WES = whole exome sequencing.

Epilepsy is a major neurologic disorder estimated to affect approximately 50 million people worldwide. ${ }^{1}$ Although proper antiepileptic drugs achieve control in $60 \%-70 \%$ of patients with epilepsy, more than one-third fail to attain seizure-free status and are diagnosed with intractable epilepsy. ${ }^{2}$ Therein, surgical resection of the epileptic focus in the affected brain is often required to relieve seizures.

The advent of sequencing technology has enabled in-depth genetic studies to identify de novo or rare germline mutations underlying intractable epilepsy. ${ }^{3,4}$ We and other groups have shown that low-level somatic activating mutations with a mutational burden (or variant allele frequency, [VAF]) of merely $1 \%$ in mTOR pathway genes, which arise only in the affected brain, are a major genetic etiology for intractable focal epilepsies with pathologically or radiologically well-defined lesions, such as focal cortical dysplasia type II (FCDII) and hemimegalencephaly (HME), exhibiting cytomegalic neurons and cortical dyslamination. ${ }^{5-9}$ In contrast to lesional focal epilepsies, such as FCDII and HME, about $15 \%-30 \%$ of intractable focal epilepsies show no abnormalities on MRI, referred to as nonlesional focal epilepsy (NLFE), or mild cortical abnormalities on pathologic examination, referred to as mild malformation of cortical development (mMCD) ${ }^{10-12}$ Although these conditions are often responsive to epilepsy surgery, ${ }^{13,14}$ the molecular genetic etiology, especially brain somatic mutations, underlying NLFE or MMCD remains elusive.

In this study, we sought to identify somatic mutations in patients with NLFE using deep whole exome sequencing (WES) and targeted amplicon sequencing and to examine the biological and pathologic functions of noted mutations in patient brain tissues.

\section{Methods}

\section{Standard protocol approvals, registrations, and patient consents}

All human tissues were obtained with informed consent in accordance with protocols approved by Severance Hospital and the KAIST Institutional Review Board and Committee on Human Research.

We first collected matched brain and peripheral blood tissues from 13 patients with NLFE subjected to epilepsy surgery; none showed an abnormal lesion on MRI (figure 1, A and B and table e-1, links.lww.com/NXG/A124). We performed deep WES (mean depth, $>800 x$ ) of extracted genomic DNA from the paired brain and peripheral tissues (table e-2). Next, to expand the study cohort, we collected matched brain and peripheral tissues from an additional 18 patients with intractable focal epilepsy: 12 with NLFE and 6 with mMCD or nonspecific gliosis in their pathologies (figure e-1A, e-1B and table e-1, links.lww.com/NXG/A124). For these patients, we performed targeted amplicon sequencing (mean depth, $1,230 \mathrm{X}$ ) of SLC35A2 in brain tissues using 12 primers overlapping at least $10 \mathrm{bp}$ and covering all exonic regions (figure e-2). To investigate the presence of mammalian target of rapamycin (mTOR) pathway mutations potentially causative of intractable epilepsy, we performed deep targeted hybrid capture sequencing (mean depth, 812X) of 10 known mTOR pathway genes (AKT3, DEPDC5, MTOR, PIK3CA, PIK3R2, PTEN, STRADA, TBC1D7, TSC1, and TSC2) in matched brain and peripheral tissues from the patients with mutations identified in SLC35A2 (table e-3 and table e-4). Furthermore, to determine whether mTOR pathway hyperactivation occurs, we performed coimmunostaining for phosphorylated S6 and NeuN, a neuronal marker, in freshly frozen brain tissue from patients carrying SLC35A2 or MTOR mutations.

For all sequencing data, we applied our analysis pipeline, inhouse filtering criteria of putative functional impact, and manual investigation using Integrative Genomic Viewer to identify potential pathogenic mutations (figure e-1, links.lww. com/NXG/A124). Noted somatic mutations were validated on a different sequencing platform, such as site-specific amplicon sequencing (read depth $>100,000 \mathrm{X}$ ). We considered variants as true positive when they appeared with a VAF greater than $1 \%, 10$ times the expected base miscall rate of $0.1 \%{ }^{15}$ Furthermore, we estimated the probability value for true positive calls of amplicon sequencing data using a previously described method. ${ }^{16}$ Briefly, this method calculates the discrepancy between expected and observed amounts of mismatches in amplicon-based, Illumina platform data sets (up to $10,000 \mathrm{X}$ ) in which 2 independent blood samples with known single nucleotide polymorphisms (SNPs) were mixed to mimic somatic mutations with 4 different VAFs: $0.5 \%, 1 \%$, $5 \%$, and $10 \%$. Then, the patterns and levels of background errors generated for the Illumina platform are identified. Based on these data, we could predict the probability value for true positive calls of targeted amplicon sequencing by considering VAFs acquired as background errors and sequencing context.

Finally, to examine whether SLC35A2 mutations affect $\mathrm{N}$-glycosylation status in the affected brain, we performed Tissue Glyco-Capture and nano liquid chromatography / mass spectrometry (nanoLC/MS) analysis, a highly sensitive 
A

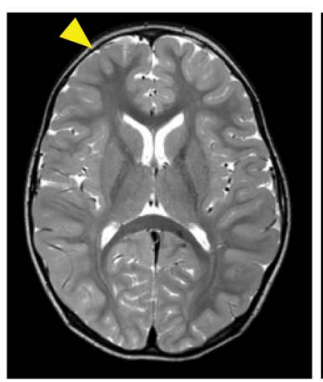

EPI219

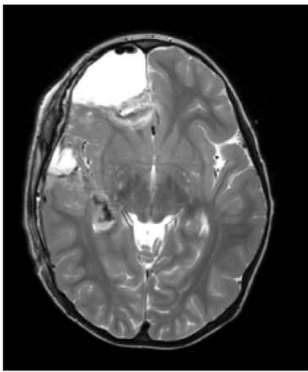

B
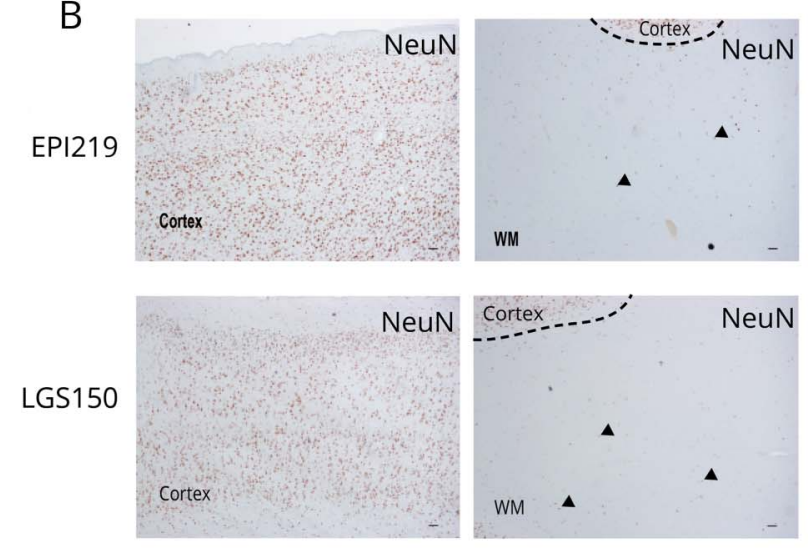

C

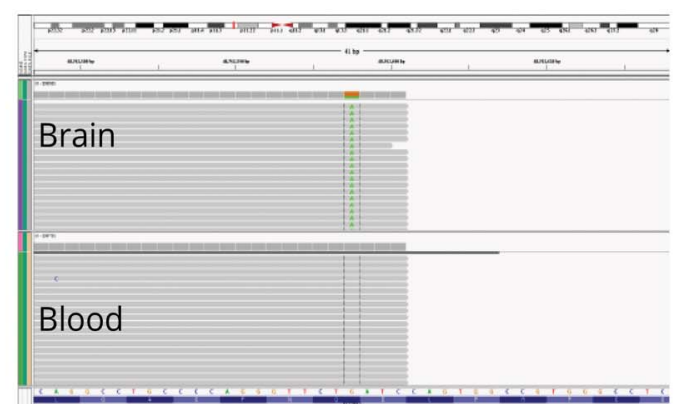

\begin{tabular}{lccc} 
& \multicolumn{3}{c}{ NLFE: LGS219 c.589C $>$ T } \\
\cline { 2 - 4 } & $\begin{array}{c}\text { Mut } \\
\text { count }\end{array}$ & $\begin{array}{c}\text { Ref } \\
\text { count }\end{array}$ & $\begin{array}{c}\text { Mut } \\
\text { allele (\%) }\end{array}$ \\
Brain & 27248 & 90058 & 23.00 \\
Blood & 34 & 103524 & 0.03
\end{tabular}

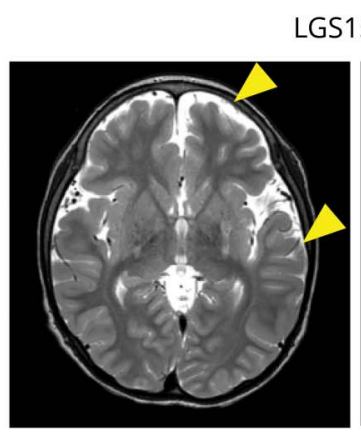

LGS150
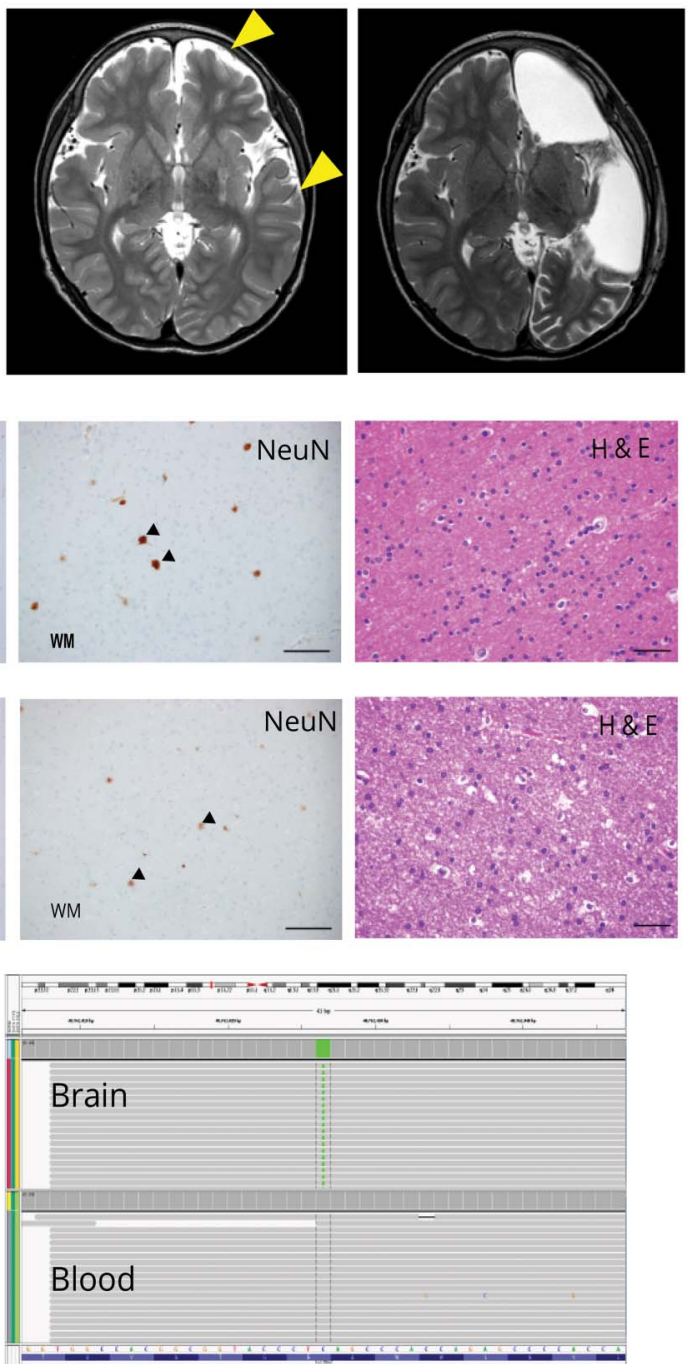

\begin{tabular}{lccc} 
& \multicolumn{3}{c}{ NLFE: LGS150 c.760G >T } \\
\cline { 2 - 4 } & $\begin{array}{c}\text { Mut } \\
\text { count }\end{array}$ & $\begin{array}{c}\text { Ref } \\
\text { count }\end{array}$ & $\begin{array}{c}\text { Mut } \\
\text { allele (\%) }\end{array}$ \\
Brain & 153585 & 753492 & 16.91 \\
Blood & 1516 & 955904 & 0.15
\end{tabular}

(A) Preoperative and postoperative brain MRI T2-weighted images from patients EPI219 and LGS150 with brain somatic mutations in SLC25A2. These T2-weighted images demonstrate no remarkable findings in the brain parenchyma, including the temporal lobe. Yellow arrowhead: putative regions of epileptic focus. (B) Histopathologic images from H \& E staining and immunohistochemical (IHC) staining from EPI219 (upper panels) and LGS150 (lower panels) brain tissues. Black arrowheads: scattered neuron in white matter. Scale bars, $40 \mu \mathrm{m}$ in $\mathrm{H}$ \& E staining and $200 \mu \mathrm{m}$ in IHC staining for NeuN, a neuronal marker (C) Capture image from integrative genomic viewer (IGV) (upper panels), showing the results of site-specific amplicon sequencing. Schematic tables (lower panels) showing the number of sequence reads counted as mutated or reference sequences, as well as the VAFs of mutated alleles. Mut: mutation, Ref: reference.

method to profile brain glycomes, ${ }^{17}$ in 2 SLC $35 A 2$ mutationcarrying brain tissues and 3 control brain tissues from patients with SLC35A2 mutation-negative NLFE and metastatic brain tumors. Detailed Methods appears in the supplemental Methods (e-Methods, links.lww.com/NXG/A125).

\section{Data availability}

Deep whole exome and targeted sequencing data will be deposited in the National Center for Biotechnology Information
Sequence Read Archive (ncbi.nlm.nih.gov/sra/). The glycosylation data are available on request.

\section{Results}

Although no pathogenic or recurrent germline mutations were identified in genes potentially linked to intractable focal epilepsy using targeted hybrid capture sequencing (table e-5 and 
Table Clinical and molecular data from patients carrying SLC35A2 mutations

\begin{tabular}{|c|c|c|c|c|c|c|c|c|c|c|c|}
\hline ID & $\begin{array}{l}\text { Sequencing } \\
\text { type }\end{array}$ & Sex & $\begin{array}{l}\text { Age at } \\
\text { surgery }\end{array}$ & Syndrome & MRI report & Pathologic diagnosis & $\begin{array}{l}\text { Engel } \\
\text { classification }\end{array}$ & $\begin{array}{l}\text { Variant allele } \\
\text { frequency }\end{array}$ & Mutation type & $\begin{array}{l}\text { Nucleotide } \\
\text { changes }\end{array}$ & $\begin{array}{l}\text { Protein } \\
\text { changes }\end{array}$ \\
\hline EPI219 & WES & M & $3 \mathrm{y}, 5 \mathrm{mo}$ & $\begin{array}{l}\text { LGS from } \\
\text { IS }\end{array}$ & $\begin{array}{l}\text { No abnormal lesion in } \\
\text { brain parenchyma, } \\
\text { ventricular system normal }\end{array}$ & $\begin{array}{l}\text { Neurons in white matter, } \\
\text { consistent with Mmcd }\end{array}$ & 4 & $23 \%$ & Stop_gained & c. $589 \mathrm{C}>\mathrm{T}$ & p.Gln197* \\
\hline LGS150 & WES & M & $5 \mathrm{y}, 3 \mathrm{mo}$ & $\begin{array}{l}\text { LGS from } \\
\text { IS }\end{array}$ & $\begin{array}{l}\text { No abnormal lesion in } \\
\text { brain parenchyma, } \\
\text { ventricular system normal }\end{array}$ & $\begin{array}{l}\text { Neurons in white matter, } \\
\text { consistent with } \mathrm{mMCD}\end{array}$ & 1 & $16 \%$ & Stop_gained & c.760 G > T & p.Glu254* \\
\hline mMCD13 & Amplicon & $\mathrm{F}$ & $5 \mathrm{y}, 1 \mathrm{mo}$ & $\begin{array}{l}\text { LGS from } \\
\text { IS }\end{array}$ & $\begin{array}{l}\text { No abnormal lesion in } \\
\text { brain parenchyma, } \\
\text { ventricular system normal }\end{array}$ & $\begin{array}{l}\text { Neurons in white matter, } \\
\text { consistent with mMCD }\end{array}$ & 1 & $10 \%$ & Missense & c.703T > G & p.Asn235Gln \\
\hline EPI340 & Amplicon & M & $4 \mathrm{y}, 2 \mathrm{mo}$ & LGS & $\begin{array}{l}\text { No abnormal lesion in } \\
\text { brain parenchyma, } \\
\text { ventricular system normal }\end{array}$ & $\begin{array}{l}\text { Neurons in white matter, } \\
\text { consistent with mMCD }\end{array}$ & 4 & $18 \%$ & Stop-gained & c. $502 \mathrm{G}>\mathrm{A}$ & p.Gln168* \\
\hline EPI147 & Amplicon & $\mathrm{F}$ & $4 y$ & LGS & $\begin{array}{l}\text { Diffuse cortical dysplasia, } \\
\text { right frontal lobe }\end{array}$ & Minimal gliosis & 1 & $6 \%$ & Stop-gained & c.553 G > A & p.Gln185* \\
\hline EPI044 & Amplicon & M & $2 \mathrm{y}, 7 \mathrm{mo}$ & $\begin{array}{l}\text { LGS from } \\
\text { IS }\end{array}$ & $\begin{array}{l}\text { No abnormal lesion in } \\
\text { brain parenchyma, } \\
\text { ventricular system normal }\end{array}$ & No abnormality & 1 & $5 \%$ & Splice-acceptor & NA & NA \\
\hline
\end{tabular}

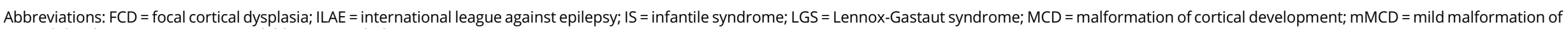
cortical development; NA = non-available; $\mathrm{WES}=$ whole exome sequencing.

All identified variants annotated based on NM_005660.1. 
table e-6, links.lww.com/NXG/A124), we surprisingly found that brain somatic mutations in SLC35A2 presented as stopgained variants, SLC35A2 c.589C > T (p.Gln197*) and c.760 G > T (p.Glu254*) on the X chromosome, in 2 of the 13 patients, respectively (table and table e-4). Both of these 2 patients (LGS150 and EPI219) were male. Their VAFs were $23 \%$ for p.Gln $197^{*}$ and $16 \%$ for p.Glu254*. Histopathologic analysis of mutation-carrying brain tissues revealed the absence of dysmorphic neurons and balloon cells, as well as any neuronal abnormality other than scattered neurons, which is consistent with $\mathrm{mMCD}$ (figure $1, \mathrm{~A}$ and $\mathrm{B}$ ). We confirmed that the 2 variants were detected only in the brain with a similar mutational burden and not in peripheral tissue by site-specific amplicon sequencing (figure 1, C). According to calculated probability values, none of the peripheral tissue sequencing data were statistically significant (table e-7).

In the additional 18 patients with intractable focal epilepsy, deep targeted sequencing of SLC35A2 in matched brainblood samples revealed brain somatic mutations in SLC35A2, c.703T > G (p.Asn235Gln), c.502 G > A (p.Gln168*), c.553 $\mathrm{G}>\mathrm{A}\left(\mathrm{p} \cdot \mathrm{Gln} 185^{*}\right)$, and chrX:48763821C > A (splice acceptor site mutation) in 4 patients ( 3 NLFE and $1 \mathrm{mMCD}$ subjects), respectively (figure e-2A, e-2B, links.lww.com/ NXG/A124 and table e-1, links.lww.com/NXG/A124). Two of the 4 patients were male. Site-specific amplicon sequencing in matched blood samples from these patients confirmed the absence of the identified somatic variants in peripheral genomic DNA (figure e-2C). The VAFs of these identified mutations ranged from $5 \%$ to $18 \%$. Calculating the probability values for amplicon sequencing data for matched peripheral tissue revealed nothing of statistical significance (table e-7). None of the identified variants in SLC35A2 were reported in the Exome Aggregate Consortium database. ${ }^{18}$ The mutations were primarily nonsense and splicing site mutations, likely acting as loss-of-function mutations (figure $2 \mathrm{~A}$ ).

To rule out the possible involvement of somatic mutations in the mTOR pathway in patients with mutations in SLC35A2, we performed deep targeted hybrid capture sequencing (mean depth, $812 \mathrm{X}$ ) of 10 known mTOR pathway genes, in which no somatic mutations were discovered. In addition, we performed coimmunostaining for phosphorylated $\mathrm{S} 6$ and $\mathrm{NeuN}$, a neuronal marker, in freshly frozen brain tissues from 2 SLC35A2 mutation-carrying patients and 1 MTOR p.A1459D mutationcarrying patient. The immunostaining results revealed marked decreases in the numbers of phosphorylated S6 stained neuron cells in patients carrying the SLC35A2 mutation (figures e-4A and e-4B, links.lww.com/NXG/A124).

SLC35A2 encodes a member of the nucleotide-sugar transporter family ${ }^{19}$ (figure $2 \mathrm{~A}$ ). The encoded protein transports uridine diphosphate (UDP)-galactose from the cytosol into Golgi vesicles, where it serves as a glycosyl donor for the generation of glycans and plays a crucial role in the galactosylation of $\mathrm{N}$-glycans. ${ }^{20}$ To examine $\mathrm{N}$-glycosylation profiles in affected brain tissue, we performed TGC and
nanoLC/MS analysis in tissues from 2 patients (EPI219 and LGS150) with SLC35A2 c.589C > T (p.Gln197*) and c.760 $\mathrm{G}>\mathrm{T}\left(\mathrm{p} . \mathrm{Glu} 254^{*}\right)$, respectively. The TGC process comprised selective enrichment steps that were critical to detecting trace amounts of glycans from brain tissue: (1) Plasma membrane extraction using ultracentrifugation isolated membrane fractions, including glycoproteins, from homogenized tissue samples. After enzymatic N-glycan release, (2) solid-phase extraction based on porous graphitized carbon was used to remove detergents (e.g., buffer chemicals and nonglycan species) and to capture solely $\mathrm{N}$-glycans. ${ }^{17,21}$ The concentrated N-glycans from each brain tissue could be determined by high sensitive nanoLC/MS analysis. The technical reproducibility and sensitivity of the combined platform of TGC and nanoLC/MS have already been demonstrated in a previous study on brain glycomes at the microgram level. Using the proven method, we found that mutation-carrying samples had less galactosylation (associated with truncated glycans without galactose residues) than control brain samples, which is consistent with a previous study ${ }^{19}$ (figure 2B). In particular, we found that mutation-carrying samples had less galactosylation than control brain samples, which is also consistent with a previous $\operatorname{study}^{22}$ (figure $2 \mathrm{~B}$ ). $\mathrm{N}$-glycan structures were unique, showing high degrees of $\mathrm{N}$-acetylglucosamine (HexNAc), such as $\mathrm{Hex}_{3} \mathrm{HexNAc}_{7} \mathrm{Fuc}_{1}$ and $\mathrm{Hex}_{3} \mathrm{HexNAc}_{8} \mathrm{Fuc}_{1}$, on high sensitive LC/MS analysis (figure 2, B and C). The glycan representing the ion at $\mathrm{m} / \mathrm{z}$ 1036.90, corresponding to $\left[\mathrm{Hex}_{3} \mathrm{HexNAc}_{7} \mathrm{Fuc}_{1}+2 \mathrm{H}\right]^{2+}$, was identified by collision-induced dissociation MS/MS (figure 2C). In sequence, the initial loss of HexNAc residues was clearly observed from the parent ion, indicating that $5 \mathrm{HexNAc}$ residues were linked to the $\mathrm{N}$-glycan core (i.e., $\mathrm{Man}_{3} \mathrm{GlcNAc}_{2}$ ). These results suggest that somatic loss-of-function mutations in SLC35A2 lead to aberrant N-glycan patterns of $\mathrm{Hex}_{3} \mathrm{HexNAc}_{7} \mathrm{Fuc}_{1}$ in patient brain tissues.

\section{Discussion}

This study suggests that brain somatic mutations in SLC $35 A 2$ explain 19.3\% (6 of 31) of intractable focal epilepsies with NLFE or mMCD and result in aberrant N-glycan patterns in mutation-carrying brain tissues. NLFE or mMCD account for $15 \%-30 \%$ of intractable childhood epilepsies. Similar to other intractable childhood epilepsies, patients with NLFE or mMCD often undergo surgical intervention; however, only $30 \%$ became seizure free after surgical treatment compared with $62 \%-80 \%$ of patients with lesional focal epilepsy. ${ }^{13,14}$ Although many research groups have studied the molecular genetic etiology underlying intractable childhood epilepsies, these studies have primarily investigated mechanisms underlying lesional epilepsy, such as malformations of cortical development, tumors, and other circumscribed anomalies. Therefore, the mechanisms underlying NLFE or mMCD have remained obscure.

An association between SLC35A2 and seizure has been suggested. In previous studies, it was reported that de-novo germline mutations or postzygotic mosaic mutation in SLC35A2 
Figure 2 Patient brain tissues with somatic mutations in SLC35A2 encoding a UDP-galactose transporter exhibiting aberrant N-glycosylation

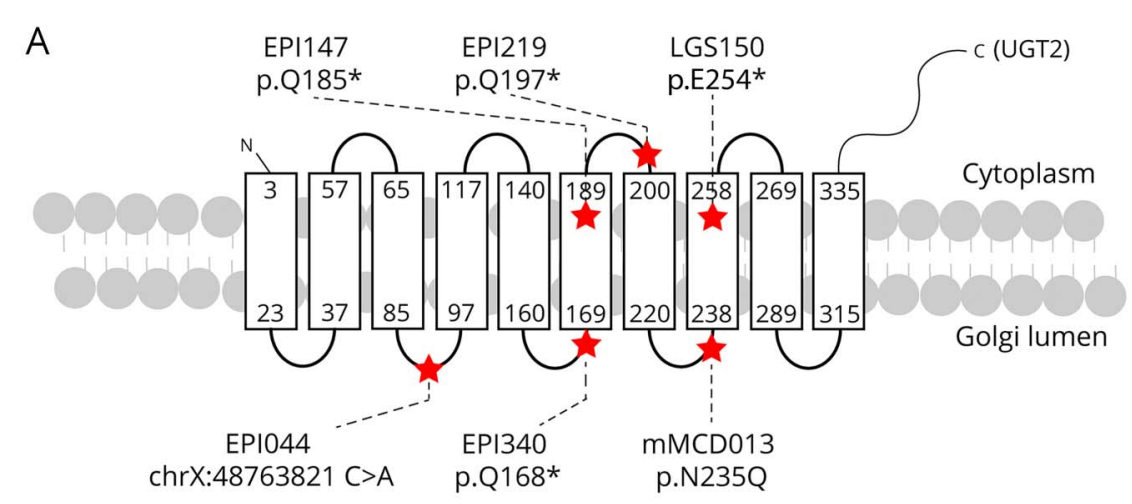

B Mutation-carrying brain tissues
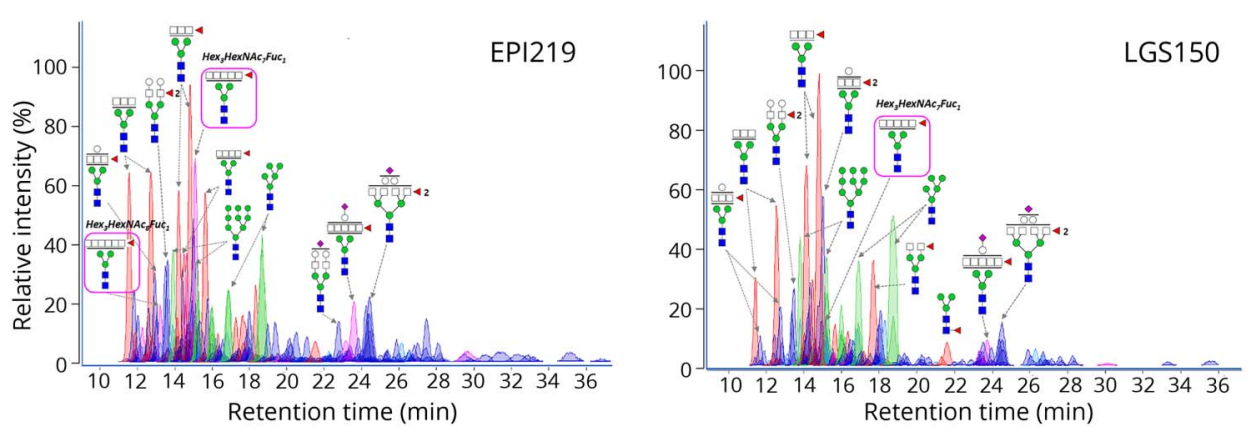

Glycan:

Control brain tissues
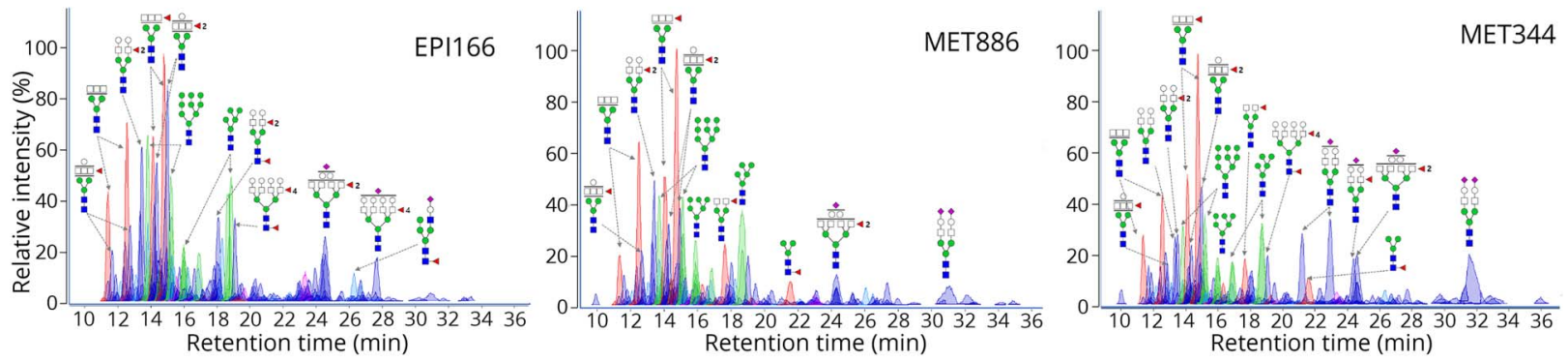

C

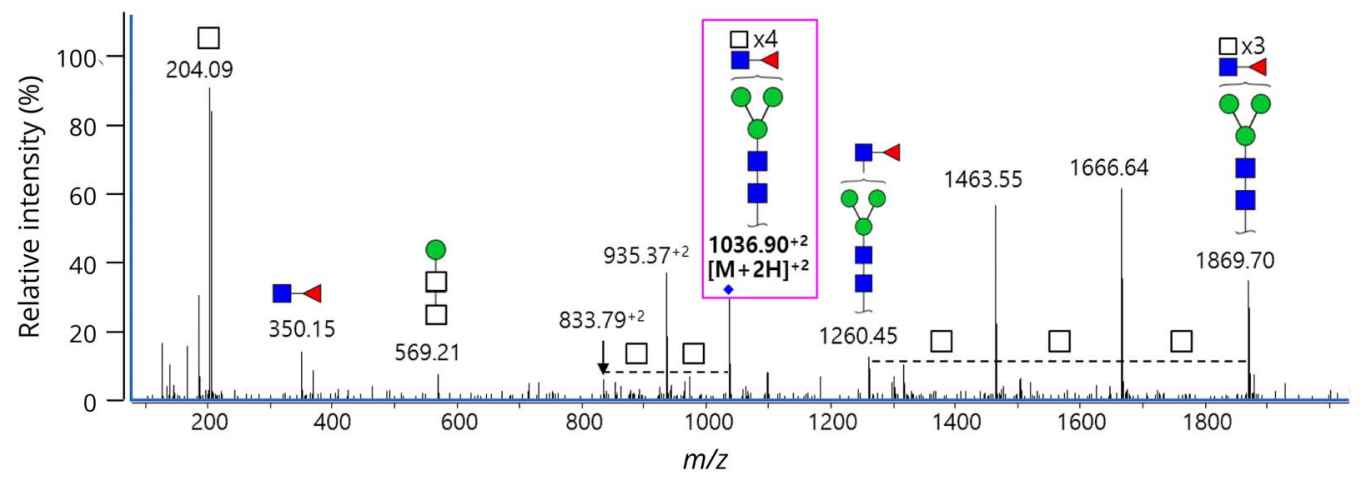

(A) Schematic figure showing brain somatic mutations in SLC35A2 identified in this study. Red star: locations of each identified mutation (B) Extracted compound chromatograms (ECCS) of N-glycans from brain tissues. EPI219 and LGS150: subjects carrying somatic mutations in SLC35A2. Control EPI166: patient with intractable focal epilepsy confirmed to have no specific somatic or germline mutations in deep WES. Control MET886 and MET344: specimens from the tumor-free margin of individuals with a metastatic tumor as part of a planned resection. These specimens were pathologically confirmed as normal brain tissue. The ECCs were color coded according to N-glycosylation types: blue for complex-type glycans containing galactose residues, red for truncated-type glycans, green for high mannose glycans, sky blue for hybrid-type glycans, and pink for the glycans involving high degrees of HexNAc residues. Pink round rectangle square: N-glycan structures showing high degrees of $\mathrm{N}$-acetylglucosamine (HexNAc), such as Hex $\mathrm{H}_{3} \mathrm{HexNAc}_{7} \mathrm{Fuc}_{1}$ and $\mathrm{Hex}_{3} \mathrm{HexNAC}_{2} \mathrm{Fuc}_{1}$ (C) Representative CID MS/MS spectrum of aberrant $\mathrm{N}$-glycan Hex ${ }_{3} \mathrm{HexNAc}_{7} \mathrm{Fuc}_{1}$ in the positive ion detection mode. Almost all fragment ions were single-protonated ions [M $\left.+\mathrm{H}\right]++$; others are indicated as a superscript. Pink square: $\mathrm{Hex}_{3} \mathrm{HexNAc}_{7} \mathrm{Fuc}_{1}$ glycan, identified by collision-induced dissociation MS/MS, representing the ion at M/Z 1036.90 . 
cause a congenital disorder of glycosylation and early-onset epileptic encephalopathy with epileptic seizures. ${ }^{22-24}$ Therein, aberrant glycosylation was found in patient fibroblasts and whole serum. ${ }^{22}$ Treatment with an oral galactose supplement improved clinical symptoms in 1 case. ${ }^{23}$ Although they support our results, these studies are limited in their ability to draw causative links between the SLC35A2 mutation and seizure development. More recently, 1 study reported that somatic mutations in SLC35A2 are associated with intractable neocortical epilepsy. ${ }^{25}$ They found somatic mutations in 3 of 18 patients with NLFE and 2 of 38 patients with malformation of cortical development or focal cortical dysplasia. However, no evidence of alterations in glycosylation in affected brain tissues was given. The present study provides stronger evidence that brain somatic mutations in SLC35A2 cause intractable focal epilepsy with NLFE or MMCD through aberrant $\mathrm{N}$-glycosylation only in the affected brain and that SLC35A2 mutations are unlikely to lead to hyperactivation of the mTOR pathway using targeted hybrid capture sequencing and immunostaining for phosphorylated S6. Several studies have explored the effects of N-linked glycosylation on glycoproteins involved in neural physiology, demonstrating essential roles of $\mathrm{N}$-glycan structures in neural circuitry. ${ }^{26} \mathrm{~N}$-glycans play specific modulatory roles controlling neural transmission and the excitability of neural circuits. Of interest, 1 study has shown that $\mathrm{N}$-glycosylation defects elicit epileptic discharges. ${ }^{27}$ Therefore, we suggest that $\mathrm{N}$-glycosylation defects caused by SLC $35 A 2$ mutations might alter neural transmission and the excitability of neural circuits, thereby resulting in seizures. Future studies using matrix-assisted laser desorption/ ionization Fourier transform mass spectrometry with nonspecific proteolysis and deglycosylation will be necessary to address the determination of N-glycosylation sites. ${ }^{28}$ Through these experiments, candidates of functionally altered proteins causing intractable epilepsies could be identifiable. Last, identifying target proteins associated with the aberrant $\mathrm{N}$-glycosylation observed in the brain may provide novel therapeutic targets or molecular diagnostic markers for intractable focal epilepsies stemming from NLFE or mMCD.

\section{Author contributions}

N.S. Sim and J.H. Lee: organized the project. N.S. Sim and J.S. Lim: performed genetic studies. S.H. Kim: performed pathologic study. N.S. Sim and J.S. Lim: performed data analysis and bioinformatics analysis. H. Son and S.W. Kim: performed amplicon sequencing data analysis. D.S. Kim, S.H. Kim, and H.C.K.: performed surgeries, collected patient samples, and managed patient information and tissues samples, along with S.H. Kim, H.D. Kim, and W.K. Kim. H.J. An and Y. Seo: performed the analysis of glycosylation in patient tissues. N.S. Sim and J.H. Lee: wrote the manuscript. D.S. Kim, S.H. Kim, H.C.K., and J.H. Lee: led the project and oversaw the manuscript preparation.

\section{Study funding}

This work was supported by grants from the Korean Health Technology R\&D Project, Ministry of Health \& Welfare,
Republic of Korea (H16C0415 to D.S.K and J.H.L; HI15C1601 to H.C.K).

\section{Disclosure}

N. S. Sim has received research support from the Korean Health Technology R\&D Project, Ministry of Health \& Welfare, Republic of Korea. Y. Seo reports no disclosures. J. S. Lim has received research support from the Korean Health Technology R\&D Project, Ministry of Health \& Welfare, Republic of Korea. W. K. Kim is/has been employed by SoVarGen and has received research support from the Korean Health Technology R\&D Project, Ministry of Health \& Welfare, Republic of Korea. H. Son has received research support from the Korean Health Technology R\&D Project, Ministry of Health \& Welfare, Republic of Korea. H. D. Kim, S. Kim, and H. J. An report no disclosures. H.C. Kang has received research support from the Ministry of Food and Drug Safety, Republic of Korea. S. H. Kim serves/has served on the editorial board of the Journal of Pathology and Translational Medicine. D.S. Kim has received research support from the Korean Health Technology R\&D Project, Ministry of Health \& Welfare, Republic of Korea. J. H. Lee is/has been employed by and receives stock/stock options/board of directions compensation from SoVarGen and has received research support from the Korean Health Technology R\&D Project, Ministry of Health \& Welfare, Republic of Korea. Full disclosure form information provided by the authors is available with the full text of this article at Neurology.org/NG.

\section{Publication history}

Received by Neurology: Genetics July 27, 2018. Accepted in final form October 3, 2018.

\section{References}

1. Duncan JS, Sander JW, Sisodiya SM, Walker MC. Adult epilepsy. Lancet 2006;367: 1087-1100.

2. Schuele SU, Lüders HO. Intractable epilepsy: management and therapeutic alternatives. Lancet Neurol 2008; 7:514-524.

3. Epi4K consortium; Epilepsy Phenome/Genome Project. Ultra-rare genetic variation in common epilepsies: a case-control sequencing study. Lancet Neurol 2017; 16:135-143.

4. Epi4K consortium; Epilepsy Phenome/Genome Project; Allen AS, Berkovic SF, Cossette P, et al. De novo mutations in epileptic encephalopathies. Nature 2013;501: 217-221.

5. Blümcke I, Thom M, Aronica E, et al. The clinicopathologic spectrum of focal cortical dysplasias: a consensus classification proposed by an ad hoc task force of the ILAE diagnostic methods commission. Epilepsia 2011;52:158-174.

6. Lee JH, Huynh M, Silhavy JL, et al. De novo somatic mutations in components of the PI3K-AKT3-mTOR pathway cause hemimegalencephaly. Nat Genet 2012;44: 941-945.

7. Lim JS, Gopalappa R, Kim SH, et al. Somatic mutations in TSC1 and TSC2 cause focal cortical dysplasia. Am J Hum Genet 2017;100:454-472.

8. Lim JS, Kim WI, Kang HC, et al. Brain somatic mutations in MTOR cause focal cortical dysplasia type II leading to intractable epilepsy. Nat Med 2015;21: $395-400$.

9. Nakashima M, Saitsu H, Takei N, et al. Somatic Mutations in the MTOR gene cause focal cortical dysplasia type IIb. Ann Neurol 2015;78:375-386.

10. Kutsy RL. Focal extratemporal epilepsy: clinical features, EEG patterns, and surgical approach. J Neurol Sci 1999;166:1-15.

11. Salanova V, Markand O, Worth R, et al. Presurgical evaluation and surgical outcome of temporal lobe epilepsy. Pediatr Neurol 1999;20:179-184.

12. Palmini A, Najm I, Avanzini G, et al. Terminology and classification of the cortical dysplasias. Neurology 2004;62:S2-S8.

13. Berkovic SF, McIntosh AM, Kalnins RM, et al. Preoperative MRI predicts outcome of temporal lobectomy: an actuarial analysis. Neurology 1995;45:1358-1363.

14. Tellez-Zenteno JF, Hernandez Ronquillo L, Moien-Afshari F, Wiebe S. Surgical outcomes in lesional and non-lesional epilepsy: a systematic review and meta-analysis. Epilepsy Res 2010;89:310-318. 
15. Shirley MD, Tang H, Gallione CJ, et al. Sturge-Weber syndrome and port-wine stains caused by somatic mutation in GNAQ. N Engl J Med 2013;368:1971-1979.

16. Kim J, Kim D, Lim JS, et al. Accurate detection of low-level somatic mutations with technical replication for next-generation sequencing. bioRxiv 2017: 179713

17. Ji IJ, Hua S, Shin DH, et al. Spatially-resolved exploration of the mouse brain glycome by tissue glyco-capture (TGC) and nano-LC/MS. Anal Chem 2015;87: 2869-2877.

18. Lek M, Karczewski KJ, Minikel EV, et al. Analysis of protein-coding genetic variation in 60,706 humans. Nature 2016;536:285-291.

19. Hadley B, Maggioni A, Ashikov A, Day CJ, Haselhorst T, Tiralongo J. Structure and function of nucleotide sugar transporters: current progress. Comput Struct Biotechnol J 2014;10:23-32.

20. Sosicka P, Jakimowicz P, Olczak T, Olczak M. Short N-terminal region of UDPgalactose transporter (SLC35A2) is crucial for galactosylation of N-glycans. Biochem Biophys Res Commun 2014;454:486-492.

21. An HJ, Gip P, Kim J, et al. Extensive determination of glycan heterogeneity reveals an unusual abundance of high mannose glycans in enriched plasma membranes of human embryonic stem cells. Mol Cell Proteomics 2012;11: M111.010660.
22. Ng BG, Buckingham KJ, Raymond $\mathrm{K}$, et al. Mosaicism of the UDP-galactose transporter SLC35A2 causes a congenital disorder of glycosylation. Am J Hum Genet 2013;92:632-636.

23. Dörre K, Olczak M, Wada Y, et al. A new case of UDP-galactose transporter deficiency (SLC35A2-CDG): molecular basis, clinical phenotype, and therapeutic approach. J Inherit Metab Dis 2015;38:931-940.

24. Kodera H, Nakamura K, Osaka H, et al. De novo mutations in SLC35A2 encoding a UDP-galactose transporter cause early-onset epileptic encephalopathy. Hum Mutat 2013;34:1708-1714.

25. Winawer MR, Griffin NG, Samanamud J, et al. Somatic SLC35A2 variants in the brain are associated with intractable neocortical epilepsy. Ann Neurol 2018;83: 1133-1146.

26. Scott H, Panin VM. The role of protein N-glycosylation in neural transmission. Glycobiology 2014;24:407-417.

27. Janz R, Goda Y, Geppert M, Missler M, Sudhof TC. SV2A and SV2B function as redundant $\mathrm{Ca} 2+$ regulators in neurotransmitter release. Neuron 1999;24: 1003-1016.

28. An HJ, Peavy TR, Hedrick JL, Lebrilla CB. Determination of N-glycosylation sites and site heterogeneity in glycoproteins. Anal Chem 2003;75:5628-5637. 


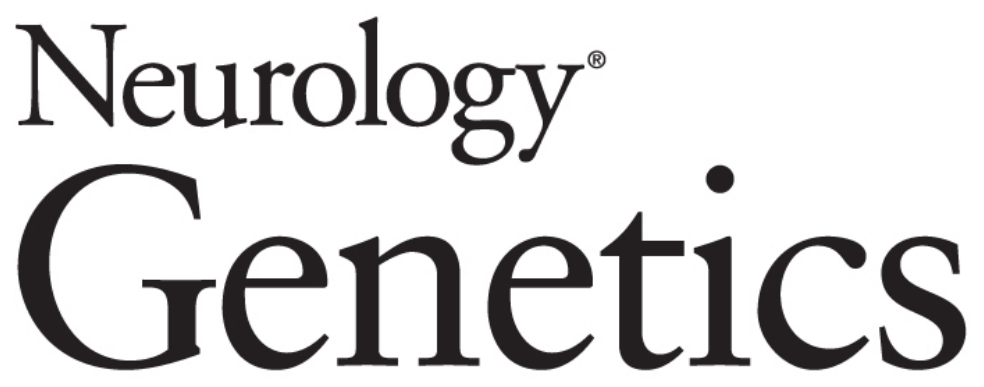
Brain somatic mutations in $S L C 35 A 2$ cause intractable epilepsy with aberrant N-glycosylation
Nam Suk Sim, Youngsuk Seo, Jae Seok Lim, et al. Neurol Genet 2018;4;
DOI 10.1212/NXG.0000000000000294

This information is current as of December 5, 2018

Neurol Genet is an official journal of the American Academy of Neurology. Published since April 2015, it is an open-access, online-only, continuous publication journal. Copyright Copyright @ 2018 The Author(s). Published by Wolters Kluwer Health, Inc. on behalf of the American Academy of Neurology.. All rights reserved. Online ISSN: 2376-7839.

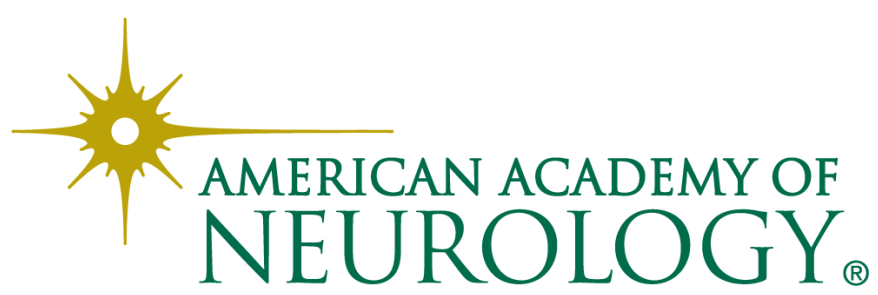




\section{Updated Information \& Services}

References

Citations

Subspecialty Collections

Permissions \& Licensing

Reprints including high resolution figures, can be found at: http://ng.neurology.org/content/4/6/e294.full.html

This article cites 27 articles, 0 of which you can access for free at: http://ng.neurology.org/content/4/6/e294.full.html\#\#ref-list-1

This article has been cited by 4 HighWire-hosted articles: http://ng.neurology.org/content/4/6/e294.full.html\#\#otherarticles

This article, along with others on similar topics, appears in the following collection(s):

All Epilepsy/Seizures

http://ng.neurology.org//cgi/collection/all_epilepsy_seizures All Genetics

http://ng.neurology.org//cgi/collection/all_genetics

Developmental disorders

http://ng.neurology.org//cgi/collection/developmental_disorders

Information about reproducing this article in parts (figures,tables) or in its entirety can be found online at:

http://ng.neurology.org/misc/about.xhtml\#permissions

Information about ordering reprints can be found online:

http://ng.neurology.org/misc/addir.xhtml\#reprintsus

Neurol Genet is an official journal of the American Academy of Neurology. Published since April 2015, it is an open-access, online-only, continuous publication journal. Copyright Copyright $\odot 2018$ The Author(s). Published by Wolters Kluwer Health, Inc. on behalf of the American Academy of Neurology.. All rights reserved. Online ISSN: 2376-7839.

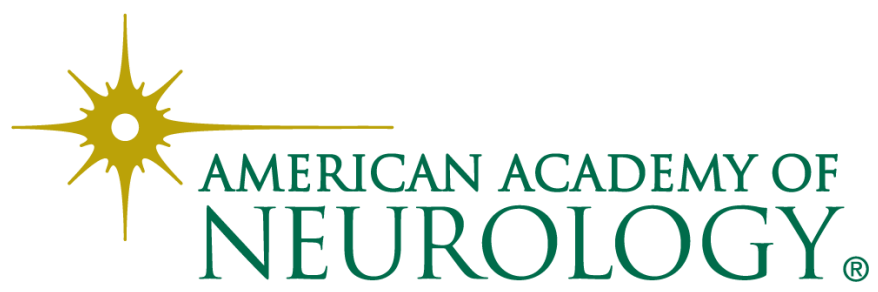

